\title{
Child mortality of children aged 5-15 years in the UK and Sweden: a comparison
}

Parag Tambe, Helen M Sammons, Imti Choonara

Academic Unit of Child Health, University of Nottingham, Derbyshire Children's Hospital, Derby, UK

Corresponding author:

Imti Choonara

Emeritus Professor in Child Health

Academic Unit of Child Health

The Medical School

University of Nottingham

Derbyshire Children's Hospital

Uttoxeter Road

Derby DE22 3DT

490 words 
Child mortality is higher in the UK than in many other European countries. We have previously compared mortality rates of children under the age of five years in the UK with Sweden [1]. We therefore decided to look at mortality rates of children between the ages of 5 and 15 years in both countries.

The methodology was similar to that used in our previous paper [1]. Child mortality cause-specific data were obtained from the respective National Statistics Offices. Because of the limitations of ICD classification, we used a more clinically useful classification to specifically identify infections [1]. Additionally, other respiratory disorders (J98) were analysed and classified clinically.

Data combined for three years were analysed. Chi-squared test was used to compare the number of deaths. Mortality rates (per 1,000,000 children were calculated for each of the three years. Mean mortality rates for the three years were used for direct comparison between the two countries.

There were 2,342 and 207 deaths in children aged $5-15$ years in the UK and Sweden, respectively, between 2006 and 2008. The mean population of children aged $5-15$ years for the same time period was 7,403,933 and 1,146,061 respectively.

The overall mortality rate was significantly higher in the UK than Sweden (105.6 and 78.5 respectively, $\mathrm{p}<0.001$ ). The mortality rates for most of the common causes of death (neoplasms, diseases of the nervous system, respiratory, infectious, circulatory, endocrine and metabolic disorders) were all significantly higher in the UK (Table 1). There was no difference in the mortality rate for external causes of morbidity and mortality between the two countries. Symptoms, signs, abnormal clinical and laboratory findings not elsewhere classified were significantly higher in Sweden. There were however only nine of these unclassified deaths in Sweden and 23 in the UK.

The greatest difference, with a mortality rate ratio of 14.2, was in diseases of the respiratory system. Ninety seven of the 135 deaths due to respiratory disorders in the UK were classified as other respiratory disorders (J98). The majority of these appeared to be due to asthma and status asthmaticus. The mortality rates for asthma and status asthmaticus, respiratory infections and septicaemia were all significantly higher in the UK than in Sweden (Table 2). Our findings in relation to the high mortality rate for asthma are in keeping with previous studies [2]. Most childhood deaths from asthma are preventable [3].

Our findings raise questions about the organisation and delivery of services for children of all ages in the UK. Access to healthcare is an issue in many low income countries [4], but unfortunately also appears to be an issue in the UK. 
Researchers, funding agencies and the media are often more interested in clinical trials of new medicines. The higher mortality rates in relation to respiratory disorders, infections and other diseases in the UK are unlikely to be significantly changed by new medicines. Studies to improve the delivery of health care in children are urgently required. 
Table 1

Mean mortality rates of children $5-15$ years in the UK and Sweden $2006-2008$, ICD classification

\begin{tabular}{|c|c|c|c|c|c|}
\hline & & Mortality rat & 000 population & & \\
\hline ICD Code & Disease & UK & Sweden & Rate ratio & p Value \\
\hline J0 - 99 & $\begin{array}{l}\text { Diseases of the respiratory } \\
\text { system }\end{array}$ & 8.5 & 0.6 & 14.2 & $<0.001$ \\
\hline A0 - B99 & $\begin{array}{l}\text { Certain infectious and } \\
\text { parasitic diseases }\end{array}$ & 3.6 & 1.5 & 2.4 & 0.04 \\
\hline $10-99$ & $\begin{array}{l}\text { Diseases of the circulatory } \\
\text { system }\end{array}$ & 7.2 & 3.8 & 1.9 & 0.02 \\
\hline EO - 90 & $\begin{array}{l}\text { Endocrine, nutritional and } \\
\text { metabolic diseases }\end{array}$ & 7.0 & 4.1 & 1.7 & 0.05 \\
\hline D50-89 & $\begin{array}{l}\text { Diseases of the blood and } \\
\text { blood forming organs and } \\
\text { immune system }\end{array}$ & 1.8 & 1.2 & 1.5 & 0.4 \\
\hline G0 - 99 & $\begin{array}{l}\text { Diseases of the nervous } \\
\text { system }\end{array}$ & 15.1 & 10.2 & 1.5 & 0.03 \\
\hline $\mathrm{C} 0-\mathrm{D} 48$ & Neoplasms & 26.2 & 19.4 & 1.3 & 0.02 \\
\hline Q0-99 & $\begin{array}{l}\text { Congenital malformations } \\
\text { and chromosomal anomalies }\end{array}$ & 7.0 & 6.4 & 1.1 & 0.7 \\
\hline KO- 93 & $\begin{array}{l}\text { Diseases of the digestive } \\
\text { system }\end{array}$ & 2.7 & 3.2 & 0.8 & 0.9 \\
\hline V0 - Y89 & $\begin{array}{l}\text { External causes of morbidity } \\
\text { and mortality }\end{array}$ & 23.1 & 23.0 & 1.0 & 0.9 \\
\hline $\begin{array}{l}\text { FO - } 99 \\
\mathrm{HO}-95 \\
\text { LO - N90 } \\
\text { PO }-96\end{array}$ & Miscellaneous & 2.4 & 2.6 & 0.9 & 0.7 \\
\hline Ro - 99 & $\begin{array}{l}\text { Symptoms, signs, abnormal } \\
\text { clinical and laboratory } \\
\text { findings not elsewhere } \\
\text { classified }\end{array}$ & 1.0 & 2.6 & 0.4 & 0.02 \\
\hline & Overall mortality & 105.6 & 78.5 & 1.3 & $<0.001$ \\
\hline
\end{tabular}




\section{Table 2}

Mean mortality rates due to respiratory disorders and infections

\begin{tabular}{|l|c|c|c|c|}
\cline { 2 - 5 } \multicolumn{1}{c|}{} & \multicolumn{3}{c|}{ Mortality rates per 1,000,000 population } \\
\hline \multicolumn{1}{|c|}{ Disorders and infections } & UK & Sweden & Rate ratio & p Value \\
\hline Asthma and status asthmaticus & 3.4 & 0.3 & 11.3 & 0.01 \\
\hline Respiratory infections & 2.4 & 0.3 & 8.0 & 0.01 \\
\hline Septicaemia & 1.9 & 0.3 & 6.3 & 0.03 \\
\hline Other respiratory conditions & 1.7 & 0.3 & 5.7 & 0.05 \\
\hline Viral infections & 2.4 & 2.0 & 1.2 & 0.7 \\
\hline Other infections & 0.7 & 0.8 & 0.9 & 0.7 \\
\hline Meningitis & 0.4 & 0.3 & 1.3 & 0.7 \\
\hline
\end{tabular}

\section{References}

1. Tambe P, Sammons HM, Choonara I. Who do young people die in the UK? A comparison with Sweden. Arch Dis Child 2015;100: 928-931.

2. Royal College of Physicians. Why asthma still kills: The National Review of Asthma Deaths (NRAD). Published in May 2014.

3. Fletcher HJ, Ibrahim SA, Speight N. Survey of asthma deaths in the Northern region, 1970-85. Arch Dis Child 1990; 65: 163-167.

4. Choonara I. Why children do not receive treatment. Arch Dis Child 2014;99;605-606 